\section{Folk Dances as a Survival of Primitive Ritual.}

A

$\mathrm{T}$ a joint meeting of the Royal Anthropological Institute, the English Folk Dance Society, and the Folk Lore Society, held on Tuesday, November 23 , in the Parry Theatre of the Royal College of Music, Miss Violet Alford read a paper on "The Ritual Dance," which was illustrated by a number of English and other folk dances performed by members of the English Folk Dance Society. As the author dealt with the anthropological side of the dances, the illustrations were classified according to the function in primitive ritual which they were intended to fulfil, so far as this could be deduced from the character of the form in which they have survived.

The dances were therefore divided into three divisions. First, magical dances to procure food or, sometimes, the power of the animal hunted. Such a dance is "The Abbots Bromley Horn Dance," which is the only example of its kind in England and, it is believed, in Europe. This is a dance of an extremely primitive character, in which the men are dressed as deer and wear long branching antlers on their heads. The horns are kept in the church. The men, bearing these immense antlers, visit the whole parish. This is probably done as an imitative dance to ensure a supply of venison, and the dance may be compared with the well-known "Hobby Horses" and "Danse de l'Ours." A second example, the "Bean Setting" dance, is a morris dance from Headington, Oxon, which shows magical qualities, though not so ancient in spirit as the "Horn Dance." It imitates the planting of beans, beginning with a sun circle.

In the second class were dances belonging to spring festivals, processionals and maypole dances-the Whitsun morris. Such were the "Castleton Garland Procession," in which the leaf-clad king is the spirit of vegetation in person, and his spring bride and the morris dancers carry oak boughs ; and "Sellenger's Round" and "Gathering Peascods," two maypole dances which date from long before plaiting ribbons was heard of, and show evidence of touching the pole to obtain power or 'luck' from it. "The Rose" is a morris dance always danced round the maypole at Leafield, Gloucester, and " The Sherborne Jig," a solo morris dance showing an elaborate kneeling posture. The "Newcastle," which was also shown, is a round country dance and shows the development of simple rounds into a beautiful and elaborate country dance. "The Whitsun Morris" is the most highly developed type of ritual dance in England. The morris men must leap for increase like the Kouretes of ancient Crete. They appear at Whitsuntide to fetch in the spring. They have a long and interesting history and were patronised by the Church. The parish even provided the morris bells and dresses. Each dance contains sun circles and heys-a representation of the form of the sacred serpent. A group of country dances was interpolated here showing the development into ballroom dances. This is the type of dance spoken of when it was said " none but country dances were done at Court." Examples of these were "Mr. Beveridge's Maggot," meaning 'notion'; "Picking up Sticks," containing a remarkable hey; and "Nonesuch," probably named from Nonesuch House.

In the third division were dances to illustrate a later confusion of ideas of sacrifice founded on the primitive rite of killing the year god. This yearly death is seen in mummers' plays, sword dances, and occasionally in the allied morris. The ritual is known from Bulgaria to south-west Spain. "The Eynsham Morris "shows the raising of the captain as Visigothic chiefs were raised on shields. A similar dance from Spain was shown in the "Finale of the Viscaya Sword Dance" danced to its own tune, showing the raising of the captain in a lying position like a dead man. The "Askham Richard Long Sword Dance" showed the killing of the captain, and the "Winlaton Rapper Dance" gives the 'calling on song,' the ritual of the 'captain's sword,' and the display of the 'lock of swords' as a symbol of the death.

\section{University and Educational Intelligence.}

CAmbridge.-G. Bateson, St. John's College, has been appointed to the Anthony Wilkin studentship in anthropology.

The Educational Settlement Association publishes in the October number of its magazine, The Common Room, its annual report for $1925-26$. Prominence is given both in the report and in several of the magazine articles to the place of science in adult education. Science is stated to have figured in the programmes of seven of the thirteen educational settlements affiliated to the Association, the object being, in four cases, " to gain some insight into the meaning of scientific method and the change in other realms of thought which the study of science is bringing about"; in the other cases " to obtain some first-hand knowledge of every-day phenomena." Keen interest in science was shown by the Aberdeen branch of the Workers Educational Association, which asked to be "instructed in the ways of life that are exhibited by plants and animals, the idea being that these might afford useful suggestions to thoughtful men." Some account is given of the Second International Conference of Social Settlements which was held in Paris on June $30-J u l y ~ 5$, and was attended by representatives from England, the United States, Belgium, Germany, Scandinavia, Italy, Switzerland, India, and Japan. It culminated in the setting up of a committee to bring into being an International Association of Settlements, and to arrange for a third conference to take place in two years' time.

From the statement for the academic year $1925^{-26}$ recently issued by the Rhodes Trust, it appears that the number of Rhodes scholars in residence during that year was I88, of which 97 were from the British Empire and the remainder from the United States. Of the total, 42 were taking natural science and medicine, 3 mathematics, 3 education, 2 forestry or agriculture, and 4 miscellaneous subjects. The present year started with 183 Rhodes scholars and ro exscholars in residence, and three more will come into residence in January. Examination successes include four D.Phil. degrees (three in natural science and one in medicine) and three B.Sc. degrees in natural science. Notices were received during the year of forty-five publications, including translations, by Rhodes scholars; these were mostly literary productions. As usual, many Rhodes scholars represented Oxford against Cambridge in sports. A Rhodes Memorial Lectureship, to be awarded to any person who has attained eminence in science, arts, business or public life, has been founded, and the first lecturer will be Sir Robert Borden, Prime Minister of Canada from I9I I until I920. The first Rhodes Travelling Fellowships, to enable resident fellows and tutors to undertake study, especially in territories from which Rhodes scholars are derived, will be awarded in 1927. Particulars of the benefactions available under the Rhodes Trust can be obtained from the offices of the Trust, Seymour House, Waterloo Place, London, S.W.r. 